\title{
Salatiga 1870s - 1930s: Institutionalization of Structural Inequality in the Age of Free Competition
}

\author{
Yuanita Wahyu Pratiwi \\ History Department, Faculty of Cultural Sciences \\ Gadjah Mada University \\ Yogyakarta, Indonesia \\ yuanita.wahyu.p@gmail.com
}

\begin{abstract}
Salatiga was an economically potential region. It was gifted with fertile soil, good climate, and strategic location. It used to bring fortune to its inhabitants, long ago, when the island of Java still play an important role in intra-insular Indonesian trade. As the trade relation changed when Western powers came, when for the first time an unequal relation positioned Salatiga as part of periphery country working for the fortune of core countries formed, this region lost its fortune. The economy of the region became inward-oriented and driven to a non-commercial direction for two and a half century since then. Only after the implementation of liberal policies, started in 1870, this region began to gain back its economic power. This paper employs the concept of structural inequality to answer the question of why actually this can happen. Is it because liberal policies, as claimed, were able to tear down the inequality that cursed this region in the previous period? By a careful reading and analysis of resources consisted of government official documents, publications from the same time, books, articles, newspapers, and photos, I can conclude that the hypothesis wasn't true. Later data from the 1930s showed that most population of the region still lingered in poverty. What actually happened during the Liberal Period was an institutionalization of structural inequality formed in the previous period. Certain series of policies were implemented to organize a well-build, extensive, and effective system, but it was never a system that accommodates the indigenous inhabitants. The system solely stood on the side of private entrepreneurs who already and about to invest their money in this region. In facing this, indigenous people were actively playing their role, but all of those were only about being a second layer economic player.
\end{abstract}

Keywords: Institutionalization, Structural Inequality, Free Competition, Salatiga

\section{INTRODUCTION}

An administrative unit during the colonial period, in a same level with regency.

\section{Structural INEQUALITY IN SALATIGA}

According to Anis A. Dani and Arjan De Haan (2008: 3), structural inequality is a condition that arises out of attributing an unequal status to a category of people in relation to one or more other categories of people, or a relationship that is perpetuated and reinforced by a confluence of unequal relations in roles, functions, decision rights, and opportunity. Basically, it was a condition while people in one administrative unit, who supposed to get the same access to anything provided by the government, divided into some groups according to their given attributes, their position in the structure of their society, and each of those groups granted with different facilities. Because of this inequality, being such gifted, as mentioned in the introduction, didn't guarantee Salatiga to be prosperous all the time.

The structural inequality happened in two different levels. First, inequality of access to economic facilities of different groups belonged to different position in the social structure within the state. Second, inequality between the colonial state and the motherland, where the colonial state tend to be what so called peripheral state by Wallerstein, and the motherland becoming the core state. In this scheme, peripheral states always worked for the fortune of core states. Both have occurred in Salatiga during this period. In the internal case, more economic opportunity was always provided to the European and the upper social class of the indigenous people, the elites. Even though an ordinary Javanese family worked for a doubled working hour during this period, the share they got was never better than the previous period because the elites and colonizer took too many shares. In the external case, this region has been made into a source of raw material for western industries. In the 16th century, the trade relation didn't contain this kind of unfair interdependency. The very famous piece of Anthony Reid (2014: 14-66) had discussed that, in the Age of Commerce, the term he used to refer a period between 1460-1680, the trade in the Indian Ocean was as sophisticated, as crowded, and as lucrative as what we can find in Mediterranean Sea in the same time. At that time, in many aspects of life, whether the nutrition value of the inhabitants, their expenditure for consumption, and their prosperity, there were not many differences between Europeans and Southeast Asians. Lockard made it clearer by stating, "(E)ven before the Western overseas expansion that occurred between 1500 and 1914, trade had taken place over vast distances" (Lockard, 2011:273)

The inequality basically already found its shape in the middle of 17 th century. In the 17 th century, all area under the power of Mataram was experiencing a refeudalization. It happened as a result of Sultan Agung's policy to protect his remained region in Java from the VOC (Vereenigde Oost Indische Compagnie) (Burger, 1960: 79). This process contributed in strengthening the social structure of feudal society, and suppressing the commercial economy, according to Mohammad Ali (2005: 152-153), by cutting the existing trade net, route, and activity. Economic activities based in a tributary system, a non-commercial system, were then more preferred. For example, during this period, Salatiga was made into a Perdikan land. It was a free tax land, but, in exchange, 
as an area along the sides of the main road connecting Semarang and The Principalities, the people of Salatiga should provide a free service to whoever passing through the road. (Schrieke, 2016: 247)

In the following period, VOC fixed the structure as a chain of production. Rather than offering their special commodity like other previous Java's foreign business partners, the VOC preferred to enforce a monopoly. Even worse, the way the VOC ask for the commodity they want was also full of forces. (Ota, 2017:585) This VOC movement also caused the same thing, the extinction of free trade in intra-insular Java. Though not all intra-insular trade of the archipelago was being cut off, for example, it still happened under the support of EIC (British East India Company) in the eastern islands of Indonesian archipelago (Ota, 2017: 590), in Java, a region where VOC's power was strong, it mostly vanished. Besides enforcing monopoly, the VOC also exploited indigenous people by using the power of local rulers. As the VOC and local rulers both were asking shares of their harvest, the burden was doubled, but the ability of indigenous people, in fulfilling it, in the matter of production, was never enhanced. Other problem is that after the coming of VOC, the structure was then directed to a commercial purpose. Previously, of course it also used by local rulers for extracting tributaries from the people, but in a non-commercial economy, the burden will not be as demanding as during this VOC period.

The difference between the time of VOC and the following period, the Cultuur Stelsel, was insignificant. The system is basically just the same, indigenous farmer were directed to produce lucrative cash crops for the sake of Dutch colonial government. They also still relied upon the help of indigenous rulers in executing their power. Only if before VOC constitution was fluid, based on dynamic bargaining with local rulers, under the official colonial government, this production chain was fixed with a constitution. All indigenous people were projected as a colonial subject, therefore they were obliged to plant some particular cash crops and had to pay taxes in the form of certain amount of their harvest. The Cultuur Stelsel was started to save the Netherlands from bankruptcy. At that time, The Netherlands was just finished financing two big wars, The Java War, and the war in their homeland with Belgium. The second war brought a big loss because Belgium, the region that used to be Netherland's source of money, succeeded in obtaining its independence. From only trying to seek fortune, the Netherlands then needed to secure a certain amount of wealth from their colony.

Business about tropical products was never a bad idea at that time since the market in Europe was always craving for them, but it brought a lot of misfortunes to the indigenous. Elson (2002:150) said that it was a hybrid system, tied up parties consisted of local elites, the state of Netherlands East Indies, the European officers, and private enterprises to work together in sucking out Java's natural sources for their own interest. Each party has rooms to dig their own interest by forcing more the weakest component of the system: the producers. In Salatiga there was an obvious sign of maladministration during the implementation of Cultuur Stelsel. The fertile region also ended up only contributed 3$6 \%$ of total government's coffee production (Suryo, 1989: 24), though its neighbor, Kedu, that shared similar geographical condition with Salatiga, was a prominent coffee producer until 1860s (Suroyo, 2000: 163).
By the involvement of the VOC, and later the colonial government of the Netherlands East Indies through the Cultuur Stelsel, the production of Java was connected to the world market in a totally new way. Although Java also played an active rule during the Age of Commerce, the relation was different now. It was because those western expansionists created an unbalanced network. They controlled production in their tropical colonies by using armed force and monopoly, bought it in low or even no cost, and sold it for an unbelievably high price in Europe. Those western colonizers also broke the internal system of states they colonized by bribing local elites with luxury if the elites chose to be in the same boat with them.

The way structural inequality in this region formed during those centuries can be easily understood by looking at the political-economic principle of those ages. 17th to 18th century is the era of mercantilism in Europe. Mercantilism is a political-economic principle that emphasized more on the security of a country by means it's alright to sacrifice other countries opportunity to be wealthier or in peace. In this principle, wealth is understood as wealth accumulated by the state, usually in a form of precious metals such as gold or silver. It often criticized because, in mercantilism, the prosperity always belongs to entrepreneurs that close to the government, while farmers and workers are suppressed on the other side. The way VOC monopolies and Cultuur Stelsel's policies left no choices to the worker and sacrificing the prosperity of the colonized country were very much resembles the mercantilism spirit.

One of the critics toward mercantilism is known as physiocratism. In contrast, physiocrats think that entrepreneurs and governments are not productive. The most productive part of society is the worker. They are where the economic opportunity should be directed more. Got inspired by those physiocrats, there came classical theories of politicaleconomy in the second half of 18th century, brought by Adam Smith, David Ricardo, Thomas Malthus, and J.S. Mills. (Deliarnov: 21-23)

Classical theories eliminated state involvement in the economy. It encourages countries to totally rely their economy on the market. By that, they believe everyone will have the same economic opportunity. The factors that will determine their success is only one's personal motivation. Classical theories inspired the implementation of liberal policies in Netherlands East Indies since 1870. The problem is that it seemed failed in abolishing the structural inequality. Even when after that, another discourse on political economy, socialism, was emerging in Europe and influencing policy makers here to initiate some "social policies" for the indigenous people since the beginning of 20th century (Cribb, Kahin, 2012: 431), the structural inequality was stand still.

\section{FAILURE IN COMBATING STRUCTURAL INEQUALITY DURING THE LIBERAL PERIOD}

In the mid-19th century there was fresh air blowing. Started from the 1850s, the natural characteristics of Salatiga that was fertile and got a good climate, invited private entrepreneurs from The Principalities to expand their business northward to Salatiga. The region under The Principalities was experiencing massive privatization of land earlier than any other region in Central Java. Since the beginning of 19th centuries, landowners there, the royals, have already able to rent their land to private companies. Most of those lands were 
made into plantations that were cultivated with most wanted tropical products like coffee, sugar, and tobacco. In 1852, there are already 13 private coffee plantations in Salatiga (Koloniaal Verslag, 1875). It made Salatiga, from an insignificant coffee region, into the 6th biggest in the whole Netherlands East Indies (Koloniaal Verslag, 1875). Proven that this free investment way brought a better life to the region, and the previous Cultuur Stelsel was destructive to people sustainability, the discussion to implement the real and indepth liberal policies was kept rolling in the parliament in the Netherlands.

There is a classic narrative stating that liberal economy implemented since 1870 was a win-win solution. It was driven solely by how the rich the Netherlands feel bad about how pitiful was people in Java. Because of that, they started to speak up about improving the lives of indigenous people of Java in the parliament. Old studies like the writing of Burger and an official release of the Netherlands claim the event happened this way (Burger, 1960; Erkelens: 1978).

In the other way, Sartono Kartodirdjo (1990: 23) refused that narrative fiercely. He stated that Liberal policies were just another way of exploiting people. It just about how the one who become exploiter, shifted from the state to private entrepreneurs. It supported by Ricklefs, in the way he explained about Max Havelaar. The novel was pretty much an excuse for the new kind of exploitation. Max Havelaar told a story about a decent colonial man who fought for indigenous people under the tyranny of their own local ruler in the name of humanity. The villain was then not the colonizers, not the Dutch, but indigenous very own elites. The novel was regarded as a holy book by European entrepreneurs, found easily in every suitcase they bring in their journey. (Ricklefs, 2012:243)

Experts like Furnivall (1939: 148), Van Zanden and Daan Marks (2012: 153) stand in the middle of the discussion, saying that though in some ways sentimental reason behind the shift from Cultuur Stelsel to Liberal Period was true, there were stronger reasons. The substantial amount of middle class emerging in the Netherlands in the mid of 19th century was a perfect result of the Cultuur Stelsel because, at the beginning of the system, the country was really poor. The middle class then, rather than just feel sorry about the condition of people in Java, feel that they, who already possessed a powerful amount of capital, should have access to directly invest their money in the Netherlands East Indies. After that, the duty of a state was not to act as a corporation anymore. The state was just needed to make sure that the climate is always good for investment by implementing a series of policies. Simply put, to change the whole political-economic system in the Netherlands East Indies. After that, the state will just need to take a look, step aside, and let the private enterprises do the rest.

In 1870 , by capital accumulated from the profit of the Cultuur Stelsel, the Netherlands finally became a prosperous industrial country. It then ready to change the way it treated its colony from mercantilist to liberals. The Netherlands started to finally think about the prosperity of their colony, to make sure they're able to buy The Netherland's industrial products.

As the middle class in the motherland demanded, the government started to do some hard work to change the way its governmental system work. The aim was to make Netherlands East Indies suitable for free investment, so after the implementation of Agrarische Wet 1870 (Agrarian Law 1870), investors would come in an enormous number willingly. The change started in transforming system of forced labor to free labor and organizing the law of private land ownership, continued by building public infrastructures and revitalizing the bureaucracy, made the bureaucracy into a Weberian one.

The land rent system promoted by Agrarian Law 1870 gave an opportunity to people who have any plot of land to rent it to private enterprises in a certain amount decided by the government and gain money from it. This law claimed to be useful in protecting indigenous property by not letting any foreigners buy indigenous land. For a big amount of land, private enterprises can only rent from the government. What used by the government for this kind of rent was woeste groenden or wasteland (Kartodirdjo, Suryo, 1991: 80). Later on, free labor system also replaced forced labor system that commonly used in Cultuur Stelsel period (Burger, 1960: 241242). This policy attempted to internalize rational transaction deeper to indigenous people's economy. By hired as a free labor they can gain money to fulfil their daily needs, pay taxes, and even accumulate capital. The fact was, those systems didn't appear that good in front of the indigenous people. It exactly succeeded in securing land right of private land renters and providing them with a huge amount of cheap labor. Meanwhile, the indigenous concept of land ownership was too complicated to be translated to western concept of property ownership. (Kano, 2008: 51) What happened through indigenous eyes was more a loss of their economic resources since forest, that used to be a place where they collect expensive exotic forest products, free dinner ingredients, and firewood has changed into plantations (Suharto, 1998:11). The new liberal government also charged more taxes to them, so they finally have to enter the new economic chain, playing the role as a cheap labor of those plantations.

The growing plantation economy should be balanced with a massive infrastructure capacity too, so the government started to conduct many infrastructural project since the middle of 19th century. It started by reactivating broken roads and build new roads during the Cultuur Stelsel to support the mobility of the products (Suryo, 1989: 101). Then, it continued with building railroads and main roads. Railroad project was started firstly in 1867, connecting Semarang and The Principalities (Supangkat, 2007: 7-8). The last part of the railroad, from Kedungjati to Ambarawa, which was finished in 1875 (Suryo, 1989: 129), was obviously built to specifically facilitate the plantations in Salatiga (Pratiwi, 2018: 79-80). After that main road was also being build and polished. In 1930, Salatiga has already had 3 main roads consisted of 
Semarang-Ungaran-Salatiga-Surakarta provincial road, Bawen-Ambarawa-Magelang road, and Salatiga-KopengMagelang road (BPAD Jawa Tengah, No. 3248). As in the plantation case, the very first room provided for indigenous people, was to become labor in the projects. As the project finished, they undoubtedly have a better access everywhere too, but the main users were still the planters.

Beside regulating property rights and building infrastructure, liberal agenda also consisted of a serial attempt to rationalize the bureaucracy. In the name of this purpose, the government reduced the number of indigenous officials (Van Zanden, Daan Marks, 2012: 152). During the Cultuur Stelsel period, because of the centrality of their role, there were plenty of indigenous officials. They even facilitated by certain regulations for keeping them to be always able to live their fancy lifestyle. In contrast, in the just attempted modern system, this kind of special treatments can be counted as corruption. It can inflict a financial loss to both, farmers or government. As a threat, corruption began to defeated by tournee, or an inspection conducted by European officials towards districts or even smaller administrative units. According to Djoko Suryo, Tournee getting more effective in combating indigenous official's corruptions since transportation and communication matters were getting better in the last years of 19th century (Suryo, 1989: 132). While doing tournee, the colonial government also managed another policy. After had reduced in quantity, those indigenous officials have to face another challenge. Later on, colonial government counted more on someone's educational background and abilities than in their heredity when recruiting new officials (Van Zanden, Daan Marks, 2012: 155). By these attempts, a rational bureaucracy that worked effectively were hoped to come true. An effective bureaucracy can provide a better investment climate for anyone want to invest their money in Salatiga.

Though policies of the period claimed to be fairer, the fact I found and explained above didn't give a similar gaze, even although in the following period starting from 1900, the prosperity of indigenous people was getting more important. It happened due to international trend to embrace socialism and the growing of the industry which need market. In the time that also known as Ethical Period, further step to 'assist' indigenous people in entering the new system, through education, counselling, and training was taken. But again, apart from what was expected by the supporter of the policies, what exactly happened was a big confusion among the indigenous. It was because the system was transferred top down. In the making of the system, the indigenous was never been involved. It didn't accommodate the need of indigenous people. The new system had a nuance of overlapping the existing one.

Dani and De Haan (2008:15-17), when explaining about structural inequality, often mentioned apartheid, caste system, and supremacy of colonial descendants in Latin America as examples. These cases were caused by certain historical reason. For example, because colonial practice in Latin America was very much cultural, the decolonization can't really erase the dominance of the colonial descendants. This pattern didn't really happen in Europe and North America because nation formations there mostly weren't a result of colonialism. In what so-called as North regions, consensus about nation state was born from an assimilation of many minorities. That's why state formation was an agreed decision and the state is stronger. When the government is formed, it was their own government, not strange group of people suddenly happened to be a ruler for all.

In the North, high tax rate was useful in building a strong state because, beside it provides a substantial resource for state's operational cost and it will enhance citizen's sense of owning the state (Dani, De Haan, 2008: 12). Social policies also firstly originated in the North. It was founded when the industrialization started to take huge share in the state's economic life. At that time, social policy was an instrument used by workers to secure their position in the economy. (Dani, De Haan, 2008: 8) Although high tax and social policies can be found as innovative policies of the Dutch colonial government during the Liberal Period, it cannot work well in the colonial state, moreover when dealing with indigenous economic problem.

Although structural inequality that is addressed by Dani and De Haan is a recent form of structural inequality, we also can relate this process with what happened during the Dutch colonial era. At that time, Dutch colonial government, as a strange government full of colonial descendants in Latin America, was a white government presenting objectives of the first class citizens in the Netherlands East Indies. The way they actually speaks for the interest of certain part of the society eliminate the 'fair' element of liberal policies. This is also why, when they started to implement some social policies, their projections cannot meet the actual target because they're miles away in understanding the indigenous people.

For indigenous people, obstacles they meet in the Liberal period were just one among others. No protest occurred because they never know if the policies claimed to make a better living for them. An act of assistance and accommodation provided by the government sometimes even appear too strange and too frightening for these people. The pattern can be found in their relations with Chinese money lenders. Though the government provided not a small amount of money to provide micro-credits for indigenous people in the agenda of combating the absolute influence of money lenders among them, it still didn't be taken so well. People in Getasan one subdistrict in Afdeeling Salatiga, prefer money lenders than government's credit, through the interest of government credit was much lower. According to Karyono (2002: 96), it caused by people trustworthy to Chinese money lender which was bigger than theirs to European banks. It was because the money lender appeared in front of them in person, while the bank was a system that needs a certain method to access. 
Although it was a hard time for indigenous people, they earned meagre wages, they were charged by more taxes, and some of their sources of money were taken away, they keep adapted themselves in the new system. Few good things they can get from the new system were that more people coming to the region, so more market provided for anything indigenous people could sell and that there were so many job opportunity to fulfil. They started to sell things that they never sell before or they just sell in special occasion like tempe, enting-enting, etc. (Emy, 2006: 35) They started to erect street food stall wherever a crowd of workers found every lunch time. They started to be a shopkeeper in Chinese shops, a hotel janitor, or a porter in the city (Emy, 2006: 38). People in villages started to plants demanded plants like European fruits and vegetables, which the knowledge of it they got from their long-term association with Chinese or European immigrants nearby their home (Pratiwi, 2018: 101-102). Life had to go on, but they're now fulfilling their role as what Wallerstein called as a periphery country, worked for the prosperity of core countries.

\section{CONCLUSIONS}

As a region with a distinctive economic potential, liberal policies were able to make Salatiga gain back its economic power, shining as bright as they were in the 16th century. It can be seen in the way it played as a hub connecting important cities in central Java. Though the prosperity can be directly seen as we see through the net of shining railroads, great land road, huge buildings in the city, and huge green plantations, the prosperity was different than what this region had in the 16 th century. At that time, local production wasn't messed up with the global market in the same range as in the Liberal Period. International trade was simply the exchange of surpluses in one region to surpluses in the other.

What was actually happened during the Liberal Period was an institutionalization of structural inequality formed in the previous period, within and outside the state, since the dominance of Western power in the 17th century. Legalization and rationalization acts implemented through the policies of the period were institutionalizing a system that was unknown yet harmful to the majority of inhabitants: the indigenous people. That was obviously different to the claim stated by the supporters of this system.

In that matter, indigenous doesn't seem to feel betrayed. They were actively playing their role and facing the new challenge. This kind of relation, positioning all people in the world under a unified global economic system where one has very much choice and the other not is now still happening. If at that time, in the end of 19 th to the beginning of 20 th century this process happened in Salatiga, it is now still being conquered by our friends in many places in all over the world.

\section{REFERENCES}

[1] Abel Jatayu Prakosa. Diskriminasi Rasial di Kota Kolonial: Salatiga 1917-1942.

[2] Semarang: Sinar Hidoep, 2017.

[3] A.M. Djuliati Suroyo. Eksploitasi Kolonial abad XIX: Kerja Wajib di

[4] Karesidenan Kedu 1800-1890.Yogyakarta: Yayasan Untuk Indonesia,

[5] 2000 .

[6] ANRI. Memori Serah Jabatan 1921-1930 (Jawa Tengah). Jakarta: Arsip Nasional

[7] Republik Indonesia, 1977.
[8] Burger, D.H.. Sedjarah Ekonomis Sosiologis Indonesia Jilid I. Jakarta: Prandja Paramita d/h J.B. Wolters, 1960.

[9] BPAD Jawa Tengah. "Permohonan Subsidi Pembangunan Jalan Salatiga-GetasanKopeng". 26 Januari 1921. Tweede Waterstaatsafdeelingen No. 3248.

[10] Dani, Anis A., Arjan de Haan, Inclusive States: Social Policy and Structural Inequalities. Washington DC: The World Bank, 2008.

[11] Deliarnov. Ekonomi Politik. Jakarta: Erlangga, 2002.

[12] Djoko Suryo. Sejarah Sosial Pedesaan Karesidenan Semarang 1830-1900.

[13] Yogyakarta: Pusat Antar Universitas Studi Sosial Universitas Gadjah

[14] Mada, 1989.

[15] Edy Supangkat. Salatiga: Sketsa Kota Lama. Salatiga: Griya Media, 2007.

[16] Elson, R.E.. Aspects of Peasant"s Life in Early 19th Century Java. David P.

[17] Chandler dan M.C. Ricklefs ed., Nineteenth and Twentieth Century

[18] Indonesia: Essays in honour of Professor J.D. Legge. Clayton: Centre of

[19] Southeast Studies Monash University, 1986, hlm. 57-81.

[20] Emy Wuryani. Distrik Salatiga: 1900-1942. Tesis. Sekolah Pascasarjana

[21] Universitas Gadjah Mada, 2006.

[22] Erkelens, J.. Kebijaksanaan Pemerintah Hindia Belanda di Bidang

[23] Perekonomian. Jakarta: KITLV-LIPI1978

[24] Kano, Hiroyoshi. Sistem Pemilikan Tanah dan Masyarakat Desa di Jawa pada abad XIX. S.M.P Tjondronegoro dan Gunawan Wiradi. ed., Dua Abad Penguasaan

[25] Tanah: Pola Penguasaan Tanah Pertanian di Jawa dari Masa ke Masa.

[26] Jakarta: YOI, 2008, hlm. 31-100.

[27] Karyono. "Kota Salatiga: Studi tentang Perkembangan Kota Kolonial 1917-1942 .

[28] Tesis. Program Studi Ilmu Sejarah, Program Pascasarjana Universitas

[29] Gadjah Mada. Yogyakarta, 2002.

[30] Koloniaal Verslag tahun 1875.

[31] Lockard, Craig. Societies, Network and Transitions: A Global History. Boston:

[32] Wadsworth, 2011.

[33] Ota, Atsushi. "Transformation of the Maritime World in the Indonesian Archipelago". Christian Buchet (ed.). The Sea in History: The Early Modern Period. Woolbridge: The Boydell Press, 2017.

[34] Pandu Suharto. Sejarah Pendirian Bank Perkreditan Rakyat. Jakarta: Lembaga

[35] Pengembangan Perbankan Indonesia, 1998.

[36] Prince, Ge.. "Economic Policy in Indonesia, 1900-1942". J. Thomas Lindblad.

[37] ed., New Challenges in The Modern Economic History of Indonesia.

[38] Leiden: Programme of Indonesian Studies, 1993, hlm. 161-186.

[39] R. Moh. Ali. Pengantar Ilmu Sejarah Indonesia. Yogyakarta: LKiS, 2005.

[40] Reid, Anthony. Asia Tenggara dalam Kurun Niaga 14501680, Jilid I: Tanah di Bawah Angin. Jakarta: Obor, 2014.

[41] Ricklefs, M.C.. Sejarah Modern Indonesia 1200-1800. Jakarta: Serambi, 2010.

[42] Sartono Kartodirdjo. Djoko Suryo, Sejarah Perkebunan di Indonesia: Kajian

[43] Sosial-Ekonomi.Yogyakarta: Aditya Media, 1991. 
[44] Pengantar Sejarah Indonesia Baru: Sejarah Pergerakan Nasional, dari

[45] Kolonialisme sampai Nasionalisme.Jakarta: Gramedia, 1990.

[46] Seligson, Mitchell A., John T. Passe-Smith (ed.). Developent and Underdevelopment: Political Economy of Inequality. Colorado: Lyenne Rienner Publisher, 1993.

[47] Stibbe, D.G.. Encyclopaedie van Nederlandsch-Indie Derde Deel. ,S-Gravenhage:

[48] Martinus Nijhof 1919.

[49] Van Zanden, Jan Luiten, Daan Marks. Ekonomi Indonesia 1800-2010: Antara
[50] Drama dan Keajaiban Pertumbuhan. Jakarta: KompasKITLV, 2012.

[51] Wertheim, W.F., Thee Siauw Gap, "Social Change in Java 1900-1930". Pacific

[52] Affairs, Vol. 35, No. 3, 1962, hlm. 223-247.

[53] United Nations, "Concepts of Inequality". Development Issues No.1. Department of Strategy and Policy Analysis Unit, October 21 st, 2015.

[54] Yuanita Wahyu Pratiwi. "Ekonomi Salatiga pada Periode Liberal". Undergraduate thesis. Program Studi Ilmu Sejarah, Departemen Sejarah, Fakultas Ilmu Budaya Universitas Gadjah Mada, 2018. 